\title{
Potential of neem leaf-empty fruit bunch-based vermicompost as biofertiliser-cum-biopesticide: Chemical properties, humic acid content and enzymes (protease and phosphatase) activity in vermicompost (Part l)
}

\author{
Loh Khye Er ${ }^{1}$, Nor Azwady Abd. Aziz ${ }^{1 *}$, Kok Ho Yin ${ }^{1}$, Muskhazli Mustafa ${ }^{1}$, Intan Safinar Ismail ${ }^{2}$ \\ and Nur Ain Izzati Mohd Zainudin ${ }^{1}$

\begin{abstract}
${ }^{1}$ Department of Biology, Faculty of Science, Universiti Putra Malaysia, 43400 Serdang, Selangor, Malaysia. ${ }^{2}$ Department of Chemistry, Faculty of Science, Universiti Putra Malaysia, 43400 Serdang, Selangor, Malaysia.
\end{abstract}

Accepted 2 October, 2012

\begin{abstract}
The palm oil industry generates empty fruit bunch (EFB) in large quantities, which need to be optimally exploited to obtain maximum benefits from their uses. Vermicomposting of EFB with neem leaves is of great interest, as the end product might function as biofertiliser as well as biopesticide. Therefore, vermicomposting of different ratios of EFB and neem leaves using Eudrilus eugeniae as a composting agent was conducted. The results showed that the vermicompost produced was lower in $\mathrm{pH}$, total organic carbon and the $\mathrm{C} / \mathrm{N}$ ratio, but higher in humic acid content compared to the earthworm free control. The addition of neem leaves as a mixture of EFB-based vermicompost contributed to the enrichment in some important plant nutrients, such as total and available N, P, K and Ca. Results suggested that the addition of $10 \%$ neem leaves would enhance the earthworm biomass as well as nutrient contents, protease and phosphatase activity in vermicompost.
\end{abstract}

Key words: Vermicomposting, empty fruit bunch, neem leaf, chemical properties, enzyme activity.

\section{INTRODUCTION}

Malaysia, as the leading producer and exporter of palm oil in the world, produce 17.7 million tonnes of palm oil a year (MPOB, 2008). Meanwhile, almost 2.5 million tonnes of empty fruit bunch (EFB) are produced each year as the by-product. Dealing with such a huge amount of waste is a major task, as it decomposes slowly, but contains rich organic substances. If it is not dealt properly, this huge amount of organic substances may be released into the environment, leading to deterioration of the environment, for instance eutrophication of the water bodies. EFB contains a relatively high concentration of potassium ( 1.20 to $2.40 \%$ ), followed by nitrogen ( 0.34 to $0.66 \%$ ),

* $\overline{\text { Corresponding author. E-mail: azwady } @ s c i e n c e . u p m . e d u . m y . ~}$ Tel: +60389466632. Fax: +60386567454. magnesium $(0.17$ to $0.20 \%)$ and phosphorus $(0.03$ to $0.10 \%$ ) (Menon et al., 2003), and therefore could be used as a plant nutrient source. Vermicomposting of organic waste has received increasing attention, as it could reduce the volume significantly. Eastman et al. (2001) stated that vermicomposting is most appropriate for organic waste management, as it is rapid and costeffective.

Neem (Azadirachta indica) is an evergreen tree that grows commonly in tropical regions, like India, Malaysia, Indonesia, Pakistan and Africa. The leaves and fruits are known to possess insecticidal, fungicidal and nematicidal properties (Kumar, 2002). At present, it has attracted global attention due to its potential in pharmaceutical and as biopesticides. Ahmed and Grainge (1985) reported that neem contains compounds that can control over 100 species of insects, mites and nematodes. The bioactivity 
Table 1. Details on composition of vermibeds used in the present study.

\begin{tabular}{ll}
\hline Treatment & Description \\
\hline VC1 & $40 \%$ neem leaves : $40 \%$ empty fruit bunch : $20 \%$ cow dung + earthworms \\
C1 & $40 \%$ neem leaves : $40 \%$ empty fruit bunch : $20 \%$ cow dung \\
VC2 & $20 \%$ neem leaves : $60 \%$ empty fruit bunch : $20 \%$ cow dung + earthworms \\
C2 & $20 \%$ neem leaves : $60 \%$ empty fruit bunch : $20 \%$ cow dung \\
VC3 & $10 \%$ neem leaves : $70 \%$ empty fruit bunch : $20 \%$ cow dung + earthworms \\
C3 & $10 \%$ neem leaves : $70 \%$ empty fruit bunch : $20 \%$ cow dung \\
VC4 & $80 \%$ empty fruit bunch : $20 \%$ cow dung + earthworms \\
C4 & $80 \%$ empty fruit bunch : $20 \%$ cow dung \\
VC5 & $100 \%$ empty fruit bunch + earthworms \\
C5 & $100 \%$ empty fruit bunch \\
\hline
\end{tabular}

VC: vermicomposting, C: control.

of neem product has been attributed to various compounds, but azadirachtin appears to be the most important compound that contributes to the insecticidal, ovicidal, antifeedant and growth-inhibiting effects against many species of insect pests (Nawrot and Harmatha, 1994). Therefore, the bioconversion of the mixture of neem leaves and EFB into potentially valuable organic amendments, such as vermicompost, is highly significant to this study.

Vermicomposting is the bio-oxidation and stabilisation of organic materials through the joint action of earthworms and microorganisms. Even though microorganisms are responsible for biochemical degradation of organic matter, earthworms are the important drivers of the process by fragmenting and conditioning the materials for microbial degradation sources (Dominguez, 2004). During passage through the worm's gut, organic matter undergoes physicochemical and biochemical changes by the combined effect of earthworms and microbial activity, thus accelerating the mineralisation of organic matter (Dominguez, 2004). Hence, vermicompost is a stabilised product having greater contents of most nutrients in forms that are more available to plants, such as nitrogen, phosphorus, magnesium, zinc, calcium, as well as contains huge numbers and types of microorganisms (Banu et al., 2001) and provides enzymes and hormones that stimulate plant growth (Doube et al., 1997).

Humic acid is another important constituent of vermicompost in terms of soil enhancer, slow release of plant nutrients, enhancement of micronutrients through chelation reaction and protection of extracellular enzymes from proteolysis (Nannipieri et al., 2002). The biochemical degradation of organic matter is mediated by a variety of enzymes, such as protease and phosphatase, which are hydrolytic enzymes involved in the nitrogen and phosphorus cycles, respectively (Aira et al., 2007). This enzyme activity has also been used as an indicator of the state of organic matter in vermicomposting sources
(Aira et al., 2007). Phosphatase catalyses the release of inorganic phosphorus from organic phosphomonoesters (Alef et al., 1995), while protease catalyses the hydrolysis of protein $\mathrm{N}$, increasing the pool of available dissolved organic N (Schimel and Bennet, 2004).

The present study was conducted to examine earthworm performance in vermicomposting different ratios of neem leaves and EFB as vermicomposting media. The quality of vermicomposts produced was examined through their chemical composition, humic acid content as well as biochemical properties (protease and phosphatase activity) of the final products.

\section{MATERIALS AND METHODS}

\section{Substrate and vermicomposting process}

Neem leaves were collected from the area around Universiti Putra Malaysia, UPM. EFB was collected from a palm oil mill in Selangor, Malaysia. Fresh cow dung was obtained from Taman Pertanian Universiti, UPM. The neem leaves, EFB and cow dung were individually dried in direct sunlight for two weeks, with periodic turning.

The dried materials were grounded and sieved through $2 \mathrm{~mm}$ sieve. Adult earthworms, Eudrilus eugeniae were randomly picked from stock culture maintained in the laboratory with EFB and cow dung as culturing substrate.

Round containers of $3-\mathrm{L}$ capacity were filled with $250 \mathrm{~g}$ feed mixture (dry weight) containing different proportion of neem leaves, EFB and cow dung (Table 1). EFB was added to the feed mixture as bulking material and cow dung (20\%) was added as a food supplement to the worms as recommended by Palta and Bhatnagar (2007). The initial nutrient content of the mixture of raw materials is shown in Table 2. These mixtures were manually turned occasionally for four weeks in order to eliminate volatile toxic substances. After four weeks, six earthworms, weighing approximately one gram live weight per individual, were introduced into five distinct groups (from VC1 to VC5), four replicates each. Mixture moisture content was maintained at $80 \%$ by periodic sprinkling of distilled water. All the containers were kept in the dark at room temperature $\left(26 \pm 1^{\circ} \mathrm{C}\right)$. All containers were vermicomposted for two months. For each treatment, natural 
Table 2. Initial chemical characteristics of mixture of neem leaves, EFB and cow dung in different ratio (mean \pm standard error, $n=4)$.

\begin{tabular}{lccccc}
\hline Parameter & T1 & T2 & T3 & T4 & T5 \\
\hline $\mathrm{pH}$ & $5.94 \pm 0.16$ & $6.21 \pm 0.11$ & $6.27 \pm 0.05$ & $6.33 \pm 0.15$ & $5.71 \pm 0.06$ \\
Organic C $(\%)$ & $50.05 \pm 0.30$ & $51.41 \pm 0.36$ & $50.99 \pm 0.28$ & $51.26 \pm 0.42$ & $52.32 \pm 0.52$ \\
Total $\mathrm{N}\left(\mathrm{mgg}^{-1)}\right.$ & $14.33 \pm 0.27$ & $12.48 \pm 0.80$ & $9.78 \pm 1.10$ & $8.13 \pm 0.57$ & $7.16 \pm 0.33$ \\
$\mathrm{C} / \mathrm{N}$ & $34.96 \pm 0.52$ & $41.72 \pm 2.85$ & $54.30 \pm 6.42$ & $64.06 \pm 4.82$ & $73.60 \pm 3.88$ \\
Total P $\left(\mathrm{mgg}^{-1}\right)$ & $2.19 \pm 0.14$ & $2.55 \pm 0.10$ & $2.06 \pm 0.22$ & $1.55 \pm 0.14$ & $1.11 \pm 0.05$ \\
Total $\mathrm{K}\left(\mathrm{mgg}^{-1}\right)$ & $4.94 \pm 0.29$ & $4.41 \pm 0.33$ & $2.69 \pm 0.09$ & $1.79 \pm 0.10$ & $0.85 \pm 0.02$ \\
Total $\mathrm{Ca}\left(\mathrm{mgg}^{-1}\right)$ & $11.60 \pm 0.62$ & $11.28 \pm 0.63$ & $6.74 \pm 0.49$ & $3.89 \pm 0.22$ & $3.44 \pm 0.11$ \\
Total $\mathrm{Mg}\left(\mathrm{mgg}^{-1}\right)$ & $2.88 \pm 0.11$ & $3.14 \pm 0.04$ & $2.55 \pm 0.13$ & $2.15 \pm 0.15$ & $1.83 \pm 0.06$ \\
\hline
\end{tabular}

T1: 40\%N:40\%EFB:20\%CD, T2: 20\%N:60\%EFB:20\%CD, T3: 10\%N:70\%EFB:20\%CD, T4: 80\%EFB:20\%CD, T5: $100 \% E F B$.

decomposition (without worms) in a similar setup was also conducted to serve as control. Finally, watering was stopped and vermicompost was harvested. Earthworms were sorted out carefully from the vermicompost, washed with distilled water to remove any adhering materials and weighed on a live weight basis.

\section{Chemical analysis}

Homogenised moist samples were used for available $\mathrm{N}$ analysis (Page et al., 1982). The remaining samples were air dried and grounded to pass through a $2 \mathrm{~mm}$ sieve. The $\mathrm{pH}$ was determined in $1: 10(\mathrm{w} / \mathrm{v})$ water extract analysis (McLean, 1982); total organic carbon was determined by ashing at $550^{\circ} \mathrm{C}$ for four hours (Lazcano et al., 2008) and a modified Kjeldahl method was used for total nitrogen $(N)$ determination. For total phosphorus $(P)$, potassium $(K)$, calcium $(\mathrm{Ca})$ and magnesium $(\mathrm{Mg})$ analysis, a microwave digestion method was employed; for available $\mathrm{P}, \mathrm{K}, \mathrm{Ca}$ and $\mathrm{Mg}$ analysis, the Mehlich 3 method was used for digestion. The digested samples were then analysed by using inductively coupled plasma mass spectrometry (ICP-MS). The carbon to nitrogen $(\mathrm{C} / \mathrm{N})$ ratio was determined for all samples. The samples were also analysed for the humic acid content by using an alkali/acid fractionation procedure (Valdrighi et al., 1996).

\section{Biochemical analysis}

The enzyme activity was determined by using moist samples. For protease activity, moist sample $(0.08 \mathrm{~g})$ was supplemented with 0.5 $\mathrm{ml}$ of $0.1 \mathrm{M}$ Tris buffer ( $\mathrm{pH} 8.1$ ) and $0.5 \mathrm{ml}$ of $2 \%$ casein (Sigma). The samples were incubated at $50^{\circ} \mathrm{C}$ for one hour with shaking at $120 \mathrm{rpm}$. The samples were quickly cooled and $0.4 \mathrm{ml}$ of $17.5 \%$ trichloroacetic acid was added to stop the enzyme activity. All samples were centrifuged at $5100 \mathrm{rpm}$ for $20 \mathrm{~min}$, followed by the addition of $0.75 \mathrm{ml}$ of $2.8 \mathrm{~N}$ sodium carbonate and $0.25 \mathrm{ml}$ of threefold diluted Folin reagent to $0.5 \mathrm{ml}$ of supernatant. Protease activity was determined at $700 \mathrm{~nm}$ (Ladd and Butler, 1972) and expressed as $\mu$ mole tyrosine liberated per gram (dry weight) of compost per hour. To determine acid and alkali phosphatase activity, $0.125 \mathrm{ml}$ of $0.115 \mathrm{M} p$-Nitrophenyl phosphate ( $p N P P$ ) was used as the substrate. $0.125 \mathrm{~g}$ of moist sample was incubated at $37^{\circ} \mathrm{C}$ for one hour with $0.03 \mathrm{ml}$ toluene and $0.5 \mathrm{ml}$ of modified universal buffer (MUB), $\mathrm{pH} 6.5$ for acid phosphatase or MUB, $\mathrm{pH} 11$ for alkali phosphatase. The samples were then supplemented with $0.125 \mathrm{ml}$ of $0.5 \mathrm{M}$ calcium chloride and $0.5 \mathrm{ml}$ of $0.5 \mathrm{M}$ sodium hydroxide to stop the reaction and the $p$-nitrophenol $(p N P)$ produced in the enzymatic reactions was extracted and determined at $400 \mathrm{~nm}$ (Tabatabai, 1982). Phosphatase activity was expressed as $\mu$ mole pNP liberated per gram (dry weight) of compost per hour.

\section{Statistical analysis}

The data obtained from the present study was analysed using SPSS (Statistical Package for Social Sciences), version 17.0. The data was subjected to normality test and tested for homogeneity of variance using Levene's test. One-way Analysis of Variance (ANOVA) with post-hoc Duncan test was used to analyse the differences between treatments (T1-T5). For each treatment, T-test was employed to compare the difference between the vermicomposting (with worms) and its counterpart (earthworm free control). A significant level of $p<0.05$ was considered throughout the analysis. Pearson's correlation was used to analyse the relationship between the nitrogen content and protease activity, as well as the phosphatase activity and humic acid content.

\section{RESULTS}

\section{Earthworm performance}

Total worm biomass increased in most treatments at the end of vermicomposting except in VC1 (40\%N:40\%EFB:20\%CD), which resulted in $36.28 \%$ reduction in worm biomass (Figure 1). VC5 (100\%EFB) resulted in the highest increase in worm biomass of $102.46 \%$, followed by $77.45 \%$ in VC3 (10\%N:70\%EFB:20\%CD), $54.75 \%$ in VC2 $(20 \% \mathrm{~N}: 60 \% \mathrm{EFB}: 20 \% \mathrm{CD})$ and the lowest increment of $31.68 \%$ in VC4 (80\%EFB:20\%CD).

\section{Chemical properties}

The $\mathrm{pH}$ of vermicompost in all treatments was significantly lower, compared to the control (Table 3). In both vermicompost and control, the treatment with $40 \%$ neem leaves recorded the highest $\mathrm{pH}$. The $\mathrm{pH}$ was then decreased with a decreasing amount of neem, with the 


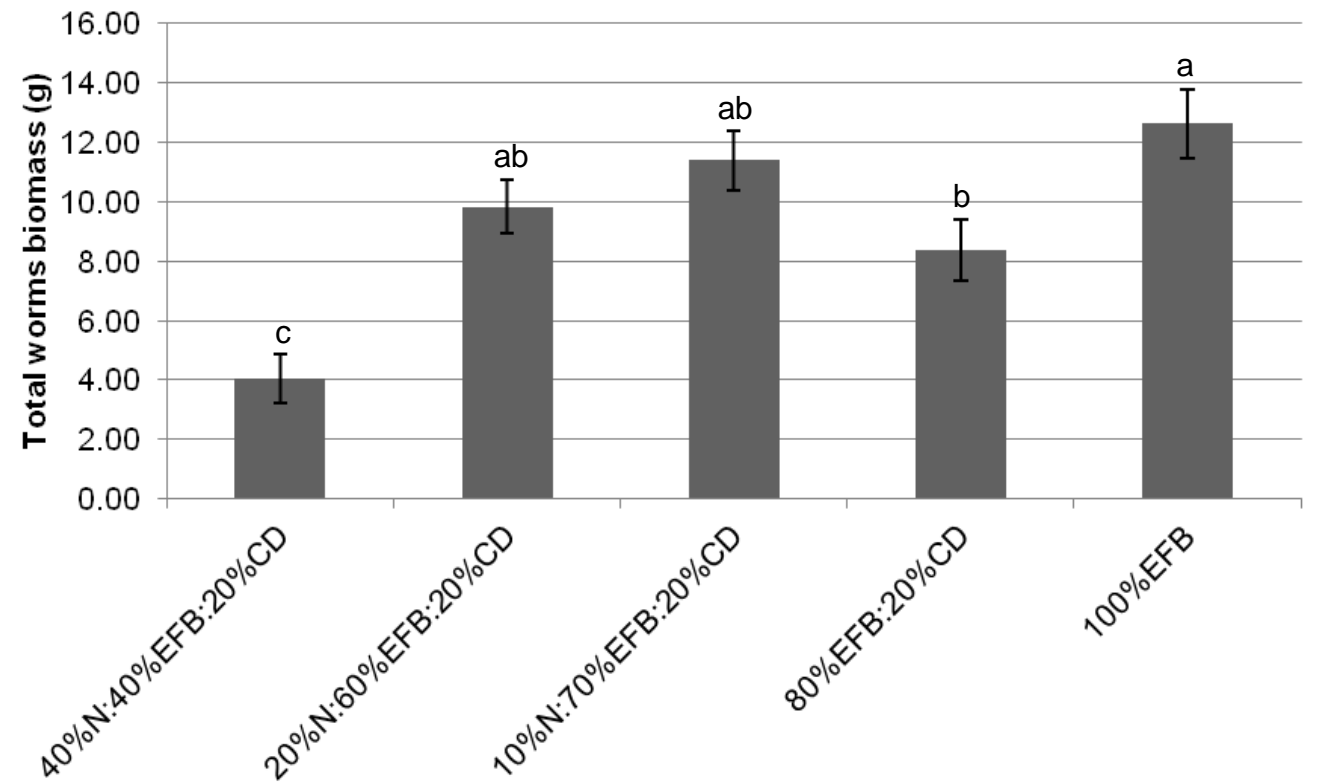

Treatments

Figure 1. Total worm biomass at the end of vermicomposting in different treatments. Values are mean \pm standard error $(n=4)$. Different letter showed significant difference $(p<0.05)$.

lowest $\mathrm{pH}$ observed in treatment with $80 \% \mathrm{EFB}: 20 \% \mathrm{CD}$ (VC4 and C4) and 100\%EFB (VC5 and C5). The total organic carbon content was significantly lower (4.65 to $18.70 \%$ in vermicompost than control. A decreasing percentage of total organic carbon was observed from $43.23 \%$ (VC1) to $39.85 \%$ (VC4) with decreasing neem composition across the treatments, except treatment with $100 \%$ EFB (VC5 and C5) that showed the highest percentage. From the results, the addition of neem leaves has been shown to increase the total and available N, P, K and $\mathrm{Ca}$ concentration in both vermicompost and control. The vermicompost and control showed a similar pattern in the total $\mathrm{N}, \mathrm{K}, \mathrm{Ca}$ and $\mathrm{Mg}$ concentration across the treatments, with T1 $(40 \% \mathrm{~N}: 40 \% \mathrm{EFB}: 20 \% \mathrm{CD})$ recording the highest concentration, followed by T2 (20\%N:60\%EFB:20\%CD), T3 (10\%N:70\%EFB:20\%CD), T4 (80\%EFB:20\%CD) and T5 (100\%EFB) in decreasing order (Table 4).

Significantly higher concentrations of available N, P, K and $\mathrm{Ca}$ were recorded in vermicompost (Table 5). T5 (VC5 and C5) showed the significantly highest available $\mathrm{N}$ concentration, followed by T1, T2, T3 and T4 in both vermicompost and control. Available $\mathrm{P}$ concentration did not differ between treatments except VC5 and C5, which showed the significantly lowest values. As for total macronutrients, a similar pattern was also observed in available $\mathrm{K}, \mathrm{Ca}$ and $\mathrm{Mg}$, which decreased across the treatments from $\mathrm{T} 1$ to $\mathrm{T} 5$ in both vermicompost and control.

$\mathrm{C} / \mathrm{N}$ ratio and humic acid are important parameters used to define the quality of vermicompost. According to Suthar (2009), a $\mathrm{C} / \mathrm{N}$ ratio below 20 is indicative of acceptable maturity. The results of the $\mathrm{C} / \mathrm{N}$ ratio and humic acid were shown in Table 3 . From the results, the $\mathrm{C} / \mathrm{N}$ of vermicompost (16.49 to 21.26) was significantly lower than control (19.52 to 22.92). The addition of $10 \%$ neem leaves in VC3 contributed to the highest reduction in $\mathrm{C} / \mathrm{N}$ of $25.42 \%$, compared to its earthworm-free control. However, the humic acid content was significantly higher in vermicompost by at least $165 \%$ than control.

\section{Biochemical properties}

The activity of protease was lower in vermicompost than control (Table 6) and correlation analysis showed a negative relationship between the protease activity and nitrogen content $(r=-0.386, p<0.05)$. The phosphatase activity was contrary to protease activity, in which vermicompost demonstrated higher activity than in the control. Phosphatase activity was positively correlated with humic acid content $(r=0.792, p<0.01)$. The highest protease activity was observed in treatment with $10 \%$ neem both in vermicompost $\left(8.32 \pm 0.25 \mu_{\text {moleg }}{ }^{-1} h^{-1}\right)$ and control $\left(16.50 \pm 0.10 \mu\right.$ moleg $\left.^{-1} h^{-1}\right)$, respectively.

\section{DISCUSSION}

\section{Earthworm performance}

Reduction in worm biomass in VC1 that may have been caused by the high percentage $(40 \%)$ of neem leaves 
Table 3. $\mathrm{pH}$, organic carbon, $\mathrm{C} / \mathrm{N}$ ratio and humic acid content in vermicompost and control of different treatments. Values are mean \pm standard error $(\mathrm{n}=4)$.

\begin{tabular}{|c|c|c|c|c|c|c|c|c|}
\hline \multirow{2}{*}{ Treatment } & \multicolumn{2}{|c|}{$\mathrm{pH}$} & \multicolumn{2}{|c|}{ Organic C (\%) } & \multicolumn{2}{|c|}{$\mathrm{C} / \mathrm{N}$} & \multicolumn{2}{|c|}{ Humic acid (\%) } \\
\hline & VC & C & VC & C & VC & C & VC & C \\
\hline $\mathrm{T} 1$ & $6.73 \pm 0.04^{\mathrm{Ba}}$ & $7.16 \pm 0.00^{\mathrm{Aa}}$ & $43.23 \pm 0.27^{\mathrm{Bb}}$ & $46.33 \pm 0.08^{\mathrm{Ac}}$ & $16.49 \pm 0.21^{\mathrm{Bb}}$ & $19.80 \pm 0.47^{\text {Acd }}$ & $1.73 \pm 0.09^{\mathrm{Ab}}$ & $0.36 \pm 0.01^{\mathrm{Ba}}$ \\
\hline $\mathrm{T} 2$ & $6.50 \pm 0.05^{\mathrm{Bb}}$ & $6.97 \pm 0.01^{\mathrm{Ac}}$ & $43.18 \pm 0.20^{\mathrm{Bb}}$ & $45.34 \pm 0.12^{\mathrm{Ad}}$ & $17.51 \pm 0.25^{\mathrm{Bb}}$ & $19.52 \pm 0.06^{\mathrm{Ad}}$ & $1.63 \pm 0.01^{\mathrm{Ab}}$ & $0.36 \pm 0.01^{\mathrm{Ba}}$ \\
\hline T3 & $6.29 \pm 0.11^{\mathrm{Bb}}$ & $7.05 \pm 0.01^{\mathrm{Ab}}$ & $41.05 \pm 0.19^{\mathrm{BC}}$ & $47.26 \pm 0.04^{\mathrm{Ab}}$ & $16.56 \pm 0.21^{\mathrm{Bb}}$ & $20.77 \pm 0.07^{\mathrm{Ac}}$ & $1.74 \pm 0.03^{\mathrm{Ab}}$ & $0.43 \pm 0.06^{\mathrm{Ba}}$ \\
\hline $\mathrm{T} 4$ & $5.60 \pm 0.08^{\mathrm{Bc}}$ & $6.60 \pm 0.00^{\mathrm{Ad}}$ & $39.85 \pm 0.51^{\mathrm{Bd}}$ & $47.30 \pm 0.17^{\mathrm{Ab}}$ & $17.47 \pm 0.84^{\mathrm{Bab}}$ & $21.83 \pm 0.17^{\mathrm{Ab}}$ & $1.59 \pm 0.08^{\mathrm{Ab}}$ & $0.46 \pm 0.07^{\mathrm{Ba}}$ \\
\hline T5 & $5.67 \pm 0.03^{\mathrm{Bc}}$ & $6.58 \pm 0.02^{\mathrm{Ad}}$ & $46.89 \pm 0.48^{\mathrm{Ba}}$ & $49.07 \pm 0.06^{\mathrm{Aa}}$ & $21.26 \pm 0.22^{\mathrm{Ba}}$ & $22.92 \pm 0.18^{\mathrm{Aa}}$ & $2.57 \pm 0.09^{\mathrm{Aa}}$ & $0.97 \pm 0.13^{\mathrm{Ba}}$ \\
\hline
\end{tabular}

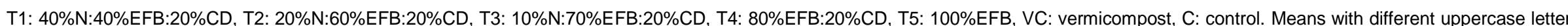
(horizontal) and different lowercase letter (vertical) showed significant difference $(p<0.05)$

Table 4. Total macronutrients concentration $\left(\mathrm{mgg}^{-1}\right)$ in vermicompost and control of different treatments. Values are mean \pm standard error $(\mathrm{n}=4)$.

\begin{tabular}{|c|c|c|c|c|c|c|c|c|c|c|}
\hline \multirow{2}{*}{ Treatment } & \multicolumn{2}{|c|}{$\mathbf{N}$} & \multicolumn{2}{|c|}{$\mathbf{P}$} & \multicolumn{2}{|c|}{$\mathbf{K}$} & \multicolumn{2}{|c|}{$\mathrm{Ca}$} & \multicolumn{2}{|c|}{ Mg } \\
\hline & VC & C & VC & C & VC & C & VC & C & VC & C \\
\hline $\mathrm{T} 1$ & $26.23 \pm 0.18^{\mathrm{Aa}}$ & $23.44 \pm 0.56^{\mathrm{Ba}}$ & $3.34 \pm 0.02^{A b}$ & $2.74 \pm 0.01^{\mathrm{Bb}}$ & $12.89 \pm 0.11^{\mathrm{Aa}}$ & $9.09 \pm 0.11^{\mathrm{Ba}}$ & $20.94 \pm 0.25^{\mathrm{Aa}}$ & $19.78 \pm 0.05^{\mathrm{Ba}}$ & $4.54 \pm 0.03^{\mathrm{Ba}}$ & $4.90 \pm 0.04^{\mathrm{Aa}}$ \\
\hline $\mathrm{T} 2$ & $24.68 \pm 0.43^{\mathrm{Ab}}$ & $23.23 \pm 0.12^{\mathrm{Ba}}$ & $3.40 \pm 0.05^{\mathrm{Aab}}$ & $2.84 \pm 0.02^{\mathrm{Ba}}$ & $10.64 \pm 0.07^{\mathrm{Ab}}$ & $6.44 \pm 0.09^{\mathrm{Bb}}$ & $14.62 \pm 0.25^{\mathrm{Ab}}$ & $13.82 \pm 0.17^{\mathrm{Bb}}$ & $4.38 \pm 0.05^{\mathrm{Bb}}$ & $4.86 \pm 0.04^{\mathrm{Aa}}$ \\
\hline T3 & $24.80 \pm 0.36^{\mathrm{Ab}}$ & $22.76 \pm 0.08^{\mathrm{Ba}}$ & $3.50 \pm 0.03^{\mathrm{Aa}}$ & $2.49 \pm 0.02^{\mathrm{Bc}}$ & $8.33 \pm 0.10^{A C}$ & $5.07 \pm 0.14^{\mathrm{Bc}}$ & $11.43 \pm 0.27^{\mathrm{Ac}}$ & $9.09 \pm 0.15^{\mathrm{Bc}}$ & $4.15 \pm 0.04^{A c}$ & $4.15 \pm 0.05^{\mathrm{Ab}}$ \\
\hline $\mathrm{T} 4$ & $22.94 \pm 0.86^{\mathrm{Ac}}$ & $21.68 \pm 0.22^{\mathrm{Ab}}$ & $3.42 \pm 0.03^{\mathrm{Aab}}$ & $2.48 \pm 0.02^{\mathrm{Bc}}$ & $7.33 \pm 0.08^{\mathrm{Ad}}$ & $3.58 \pm 0.08^{\mathrm{Bd}}$ & $8.15 \pm 0.15^{\mathrm{Ad}}$ & $6.36 \pm 0.08^{\mathrm{Bd}}$ & $4.12 \pm 0.05^{\mathrm{Ac}}$ & $4.10 \pm 0.05^{\mathrm{Ab}}$ \\
\hline $\mathrm{T} 5$ & $22.06 \pm 0.00^{\mathrm{Ac}}$ & $21.41 \pm 0.17^{\mathrm{Bb}}$ & $1.65 \pm 0.03^{\mathrm{Ac}}$ & $1.56 \pm 0.02^{\mathrm{Bd}}$ & $6.18 \pm 0.06^{\mathrm{Ae}}$ & $1.17 \pm 0.02^{\mathrm{Be}}$ & $6.21 \pm 0.12^{\mathrm{Ae}}$ & $6.09 \pm 0.07^{\mathrm{Ad}}$ & $2.86 \pm 0.04^{\mathrm{Bd}}$ & $3.54 \pm 0.04^{\mathrm{Ac}}$ \\
\hline
\end{tabular}

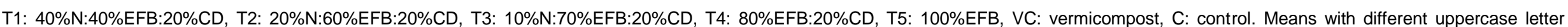
(horizontal) and different lowercase letter (vertical) showed significant difference $(p<0.05)$.

Table 5. Available macronutrients concentration $\left(\mathrm{mgg}^{-1}\right)$ in vermicompost and control of different treatments. Values are mean \pm standard error $(n=4)$.

\begin{tabular}{|c|c|c|c|c|c|c|c|c|c|c|}
\hline \multirow{2}{*}{ Treatment } & \multicolumn{2}{|c|}{$\mathbf{N}$} & \multicolumn{2}{|c|}{$\mathbf{P}$} & \multicolumn{2}{|c|}{$\mathrm{K}$} & \multicolumn{2}{|c|}{$\mathrm{Ca}$} & \multicolumn{2}{|c|}{ Mg } \\
\hline & VC & C & VC & C & VC & C & VC & C & VC & C \\
\hline $\mathrm{T} 1$ & $1.84 \pm 0.00^{\mathrm{Ab}}$ & $1.83 \pm 0.00^{\mathrm{Bb}}$ & $1.66 \pm 0.12^{\mathrm{Aa}}$ & $1.19 \pm 0.04^{\mathrm{Ba}}$ & $10.63 \pm 0.12^{\mathrm{Aa}}$ & $8.09 \pm 0.61^{\mathrm{Bab}}$ & $10.54 \pm 0.50^{\mathrm{Aa}}$ & $9.01 \pm 0.42^{\mathrm{Ba}}$ & $3.15 \pm 0.22^{\mathrm{Aab}}$ & $3.27 \pm 0.03^{\mathrm{Aa}}$ \\
\hline T2 & $1.79 \pm 0.01^{\mathrm{Ac}}$ & $1.76 \pm 0.01^{\mathrm{Bc}}$ & $1.75 \pm 0.02^{\mathrm{Aa}}$ & $1.17 \pm 0.01^{\mathrm{Ba}}$ & $8.93 \pm 0.05^{A b}$ & $6.14 \pm 0.12^{\mathrm{Ba}}$ & $8.60 \pm 0.20^{A b}$ & $5.48 \pm 0.06^{\mathrm{Bb}}$ & $3.27 \pm 0.06^{\mathrm{Aa}}$ & $3.29 \pm 0.02^{\mathrm{Aa}}$ \\
\hline T3 & $1.76 \pm 0.00^{\mathrm{Ac}}$ & $1.75 \pm 0.02^{\mathrm{Ac}}$ & $1.81 \pm 0.02^{\mathrm{Aa}}$ & $1.27 \pm 0.03^{\mathrm{Ba}}$ & $7.46 \pm 0.08^{\mathrm{Ac}}$ & $4.64 \pm 0.10^{\mathrm{Bb}}$ & $6.75 \pm 0.15^{\mathrm{Ac}}$ & $5.18 \pm 0.05^{\mathrm{Bb}}$ & $3.13 \pm 0.04^{\mathrm{Aa}}$ & $3.16 \pm 0.03^{\mathrm{Ab}}$ \\
\hline $\mathrm{T} 4$ & $1.77 \pm 0.03^{\mathrm{Ac}}$ & $1.77 \pm 0.02^{\mathrm{Ac}}$ & $1.87 \pm 0.04^{\mathrm{Aa}}$ & $1.20 \pm 0.01^{\mathrm{Ba}}$ & $6.24 \pm 0.04^{\mathrm{Ad}}$ & $3.32 \pm 0.02^{\mathrm{Bc}}$ & $5.46 \pm 0.23^{\mathrm{Ad}}$ & $3.57 \pm 0.02^{\mathrm{Bc}}$ & $3.35 \pm 0.05^{\mathrm{Aa}}$ & $3.09 \pm 0.01^{\mathrm{Bc}}$ \\
\hline T5 & $1.90 \pm 0.01^{\mathrm{Ba}}$ & $2.01 \pm 0.02^{\mathrm{Aa}}$ & $0.60 \pm 0.02^{A b}$ & $0.48 \pm 0.01^{\mathrm{Bb}}$ & $5.34 \pm 0.04^{\mathrm{Ae}}$ & $1.05 \pm 0.03^{B d}$ & $4.74 \pm 0.06^{\mathrm{Ad}}$ & $3.37 \pm 0.02^{\mathrm{Bd}}$ & $2.51 \pm 0.03^{\mathrm{Bb}}$ & $2.69 \pm 0.02^{\mathrm{Ad}}$ \\
\hline
\end{tabular}

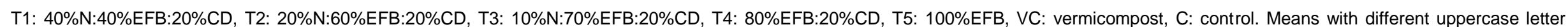
(horizontal) and different lowercase letter (vertical) showed significant difference $(p<0.05)$. 
Table 6. Protease and phosphatase activity $\left(\mu\right.$ moleg $\left.^{-1} \mathrm{~h}^{-1}\right)$ of vermicompost and control of different treatments. Values are mean \pm standard error $(n=4)$.

\begin{tabular}{lcccc}
\hline \multirow{2}{*}{ Treatment } & \multicolumn{2}{c}{ Protease } & \multicolumn{2}{c}{ Phosphatase } \\
\cline { 2 - 5 } & VC & C & VC & C \\
\hline $40 \% \mathrm{~N}: 40 \% E F B: 20 \% C D$ & $2.51 \pm 0.41^{\mathrm{Bc}}$ & $10.42 \pm 0.26^{\mathrm{Ac}}$ & $1.43 \pm 0.04^{\mathrm{Aa}}$ & $0.77 \pm 0.03^{\mathrm{Ba}}$ \\
$20 \% \mathrm{~N}: 60 \% \mathrm{EFB}: 20 \% \mathrm{CD}$ & $6.16 \pm 0.25^{\mathrm{Bb}}$ & $11.88 \pm 0.56^{\mathrm{Ab}}$ & $0.80 \pm 0.04^{\mathrm{Ad}}$ & $0.36 \pm 0.01^{\mathrm{Bb}}$ \\
$10 \% \mathrm{~N}: 70 \% \mathrm{EFB}: 20 \% \mathrm{CD}$ & $8.32 \pm 0.25^{\mathrm{Ba}}$ & $16.50 \pm 0.1^{\mathrm{Aa}}$ & $1.07 \pm 0.01^{\mathrm{Ac}}$ & $0.21 \pm 0.03^{\mathrm{Bd}}$ \\
$80 \% E F B: 20 \% \mathrm{CD}$ & $5.39 \pm 0.25^{\mathrm{Bb}}$ & $11.89 \pm 0.51^{\mathrm{Ab}}$ & $0.75 \pm 0.05^{\mathrm{Ad}}$ & $0.25 \pm 0.03^{\mathrm{Bcd}}$ \\
$100 \% E F B$ & $3.28 \pm 0.42^{\mathrm{Bc}}$ & $10.01 \pm 0.35^{\mathrm{Ac}}$ & $1.30 \pm 0.03^{\mathrm{Ab}}$ & $0.32 \pm 0.03^{\mathrm{Bbc}}$ \\
\hline
\end{tabular}

VC: vermicompost, C: control. Means with different uppercase letter (horizontal) and different lowercase letter (vertical) showed significant difference $(p<0.05)$.

contributed to a relatively higher concentration of bitter compounds, which deterred the feeding of worms. This could be explained by the fact that the triterpenoid compounds in neem are known to act on the chemoreceptors that lead to antifeedant activity on selected organisms (Mordue and Blackwell, 1993). The high amount of neem in VC1 might as well affect earthworms. The total worm biomass increased as neem decreased across the treatments (Figure 1). The lower neem concentration could probably make the materials more palatable to the worms. Suthar (2009) suggested that the additional of bulking material, such as EFB in the present study can reduce the concentration of some toxic chemicals in vermicomposting materials and, when mixing in an appropriate ratio, could support the earthworm growth.

\section{Chemical properties}

The lower $\mathrm{pH}$ in vermicompost was most probably due to the higher degree of mineralisation in vermicompost, compared to the natural decomposition (earthworm-free) materials (control). The mineralisation of nitrogen and phosphorus into ammonia, nitrites or nitrates and orthophosphates shift the $\mathrm{pH}$ of the substrates toward acidic (Ngedwa and Thompson, 2000). The production of carbon dioxide and the bioconversion of organic matters into intermediate species of organic acids may also lower the $\mathrm{pH}$ of vermicompost (Suthar, 2009). The $\mathrm{pH}$ was highest in treatment with $40 \%$ neem. This might indicate a low mineralisation rate, as neem has been shown to possess fungicidal and bactericidal properties. According to Suthar (2009), the difference in $\mathrm{pH}$ among treatments might be contributed by the quality of the organic matter in different treatments, which affects the mineralisation and subsequently the resulting species of intermediate compounds in vermibed.

The reduction in organic carbon content could be due to the fact that available carbon was utilised by the earthworms and microorganisms as an energy source.
Earthworms fragment and homogenise the ingested materials through muscular action of their foregut gizzard, adding mucus and enzymes to ingested materials. Therefore, it increases the surface area for the action of symbiotic microbes, which perform the biochemical degradation of waste material and cause carbon loss in the form of carbon dioxide (Dominguez, 2004). The differences in the organic carbon content across the treatments with different composition of materials indicated that the appropriate mixture of materials could increase the mineralisation in the vermicomposting system. This is in agreement with Suthar (2009) and Flegel and Scherder (2000), who stated that the difference in organic carbon content between treatments might be due to the different physical and chemical composition of the feedstock mixture in different ratios that influence the mineralisation process.

The observed decrease of the total $\mathrm{N}, \mathrm{K}, \mathrm{Ca}$ and $\mathrm{Mg}$ concentration from T1 to T5 might be due to variation in the substrate's initial chemical properties (Table 2). This corroborates the findings by Suthar (2009), who reported that the nutrient content of vermicompost is directly related to the chemical properties of the initial substrate.

The higher available $\mathrm{N}, \mathrm{P}, \mathrm{K}$ and $\mathrm{Ca}$ concentration in vermicompost revealed the higher mineralisation rate in vermicompost. Earthworm feeding activity modifies the physical, chemical and biological properties of organic materials, increasing its surface area exposed to microorganisms, making it more favourable for microbial activity and thus accelerating the decomposition rate (Dominguez, 2004). A decrease in $\mathrm{pH}$ may be an important factor in nitrogen retention, as this element is lost as volatile ammonia at higher $\mathrm{pH}$ values. Atiyeh et al. (2000) reported that earthworms have a great impact on nitrogen transformation so that nitrogen was retained in the nitrate form by enhancing mineralisation of nitrogen. The higher available $\mathrm{P}$ in vermicompost might attribute to the earthworm gut phosphatase, which converts insoluble $\mathrm{P}$ to a more available form, and further released by $\mathrm{P}$ solubilising microorganisms present in the casts (Lee, 1992). The humic acid in vermicompost might be 
responsible in liberating fixed $\mathrm{K}$ due to its high complexing power, which is able to adsorb to potassium ion and regulate its bioavailability in vermicompost (Tan, 1978). The carbonic anhydrase in an earthworm's calciferous gland converts excess $\mathrm{Ca}$ from ingested fungal hyphae into calcium carbonate, which is then excreted through the digestive tract and results in an increase in the $\mathrm{Ca}$ concentration in vermicompost (Yadav and Garg, 2009).

The results also demonstrated that the treatments with neem leaves contained a higher total and available $N, P$, $\mathrm{K}$ and $\mathrm{Ca}$ concentration than treatments without neem leaves. This might be due to the fact that the neem leaf is rich in $\mathrm{N}, \mathrm{P}, \mathrm{K}$ and $\mathrm{Ca}$ and has contributed significantly to the nutrient enrichment in the end product. Since Singh et al. (2009) stated that neem is an excellent fertiliser because it is rich in nutrients, the use of neem leaves as part of vermicomposting substrate is recommended, as it might also double up the biofertiliser as a biopesticide.

The present study demonstrated that the $\mathrm{C} / \mathrm{N}$ ratio of vermicompost was lower compared to control. This indicated that vermicompost has experienced an advanced degree of organic matter mineralisation and reached a satisfactory degree of maturity. The higher degree of maturation of organic matter in the vermicomposting system demonstrates the role of earthworms in accelerating the decomposition and mineralisation rate of organic matter (Yadav and Garg, 2009). The humic acid content was contrary to the $\mathrm{C} / \mathrm{N}$ ratio, with vermicompost showing a higher percentage than control. Benitez et al. (2000) demonstrated that the amount and quality of humic acid are important indicators of the chemical stability and biological maturity of vermicompost. The high humic acid content in vermicompost, which might be attributed to the fragmentation of materials by a worm's feeding activity, provides a large area for subsequent microbial humification.

\section{Biochemical properties}

The low protease activity, which might be due to the protein content available for proteolytic activity, was depleted during vermicomposting. The action of earthworms during vermicomposting could reduce substrate for enzyme activity, since earthworms are able to exploit organic $\mathrm{N}$ pools (Aira et al., 2007). The result is similar to the findings by Lazcano et al. (2008), in which vermicompost showed lower protease activity than in the conventional compost. This could be explained by the fact that protease activity is highly dependent on substrate availability (Aira et al., 2007). Thus, protease activity is a very good indicator of the level of maturity of a substrate (Aira et al., 2007). The results in the present study indicated that vermicompost experienced a higher degree of decomposition, compared to the earthworm-free control.

For the phosphatase enzyme, the higher activity was recorded in vermicompost. Higher phosphatase activity contributed to greater mineralisation; hence, higher phosphorus availability in vermicompost is shown in the present study. The accumulation and protection of extracellular enzymes in humic complexes might protect the enzymes from physical and microbial degradation. According to Nannipieri et al. (2002), humus-enzyme complexes may become inaccessible to proteases and the rigidity of the enzyme molecule may be increased with a consequential increase of its stability against thermal denaturation.

The present study showed that at a 10\% neem composition, both earthworms and microorganisms can tolerate the bioactive compounds introduced by neem leaves, resulting in an increment of enzyme activity in vermicompost.

\section{Conclusion}

Vermicomposting could be applied as an alternative technology for the management of palm oil EFB. The suitability of the vermicompost produced as an organic fertiliser was confirmed by having an ideal $\mathrm{pH}$, total organic carbon, $\mathrm{C} / \mathrm{N}$ ratio and the increase in humic acid content. The present study suggested that the addition of neem leaves into empty fruit bunch-based vermicompost contributed to the enrichment in total and available $\mathrm{N}, \mathrm{P}$, $\mathrm{K}$ and $\mathrm{Ca}$. The addition of $10 \%$ neem enhanced the nutrient contents, earthworm biomass as well as protease and phosphatase activities in vermicompost; hence, value was added to the quality of the vermicompost.

\section{ACKNOWLEDGEMENT}

The authors wish to thank the Ministry of Higher Education (MOHE) for financial support through FRGS.

\section{REFERENCES}

Ahmed S, Grainge M (1985). Use of indigenous plant resources in rural development: Potential of the neem tree. Int. J. Dev. Technol. 3:123130.

Aira M, Monroy F, Dominguez J (2007). Earthworms strongly modify microbial biomass and activity triggering enzymatic activities during vermicomposting independently of the application rates of pig slurry. Sci. Total Environ. 385:252-261.

Alef K, Nannipieri P, Trazar-Cepeda C (1995). Phosphatase activity. In: Alef K., Nannipieri P (eds) Methods in applied soil microbiology and biochemistry. Academic Press, London pp. 335-344.

Atiyeh RM, Dominguez J, Subler S, Edwards CA (2000). Change in the biochemical properties of cow manure during processing by earthworm Eisenia andrei (Bouch) and the effect of seeding growth. Pedobiologia 44:709-724.

Banu JR, Logakanthi S, Vijayalakshmi GS (2001). Biomanagement of paper mill sludge using and indigenious (Lampito mauriti) and two exotic (Eudrillus eugeniae and Eisenia foetida) earthworms. J. 
Environ. Biol. 22: 181-185.

Benitez E, Nogales R, Masciandaro G, Ceccanti B (2000). Isolation by isoelectric focusing of humic-area complexes from earthworm (Eisenia foetida) processed sewage sludge. Biol. Fert. Soils 31:489493.

Dominguez J (2004). State-of-the art and new perspectives on vermicomposting research. In: Edwards CA (ed) Earthworm Ecology, Second edition, CRC Press pp. 401-424.

Doube BM, Williams PML, Willmott PJ (1997). The influence of two species of earthworm (Aporrectodea trapezoids and Aporrectodea dearosea) on the growth of wheat, barley, and faba beans in three soil types in the greenhouse. Soil Biol. Biochem. 29: 503-509.

Eastman BR, Kane PN, Edwards CA, Trytek L, Gunadi B, Stermer L, Mobley JR (2001). The effectiveness of vermiculture in human pathogen reduction for USEPA biosolids stabilization. Compost Sci. Util. 9(1):38-49.

Flegel M, Scherde S (2000). Importance of food quality on selected enzyme activities in earthworm casts (Dendrobaena octaedra, Lumbricidae). Soil Biol. Biochem. 32:1191-1196.

Kumar U (2002). Neem as a potential biopesticide and soil conditioner. Agrobiosci. Newslett. 1(6):8-12.

Ladd JN, Butler JH (1972). Short-term assays of soil proteolytic enzyme activities using proteins and dipeptide derivatives as substrates. Soil Biol. Biochem. 4:19-30.

Lazcano C, Gomez-Brandon M, Dominguez J (2008). Comparison of the effectiveness of composting and vermicomposting for the biological stabilization of cattle manure. Chemosphere 72:1013-1019.

Lee KE (1992). Some trends opportunities in earthworm research or: Darwin's children. The future of our discipline. Soil Biol. Biochem. 24:1765-1771.

Malaysian Palm Oil Industry Performance (MPOIP) (2008). Global Oils \& Fats Bus. Mag. 6(1):14.

McLean EO (1982). Soil pH and lime requirement. In: Page AL, Miller $\mathrm{RH}$, Keeney DR (eds) Methods of Soil Analysis, Part 2, Agronomy 9, American Society of Agronomy Inc., Madison, W.I. pp. 199-224.

Menon NR, Ab-Rahman Z,Abu Bakar N (2003). Empty Fruit Bunches Evaluation: Mulch in Plantation vs. Fuel for Electricity Generation. OPIEJ 3(2):15-20.

Mordue AJ, Blackwell A (1993). Azadirachtin: An update. J. Insect Physiol. 39(11):903-924.
Nannipieri P, Kandeler E, Ruggiero P (2002). Enzyme activities and microbiological and biochemical processes in soil. In: Burns RG, Dick $R$ (eds) Enzymes in the environment, New York, pp. 1-33.

Nawrot J, Harmatha J (1994). Natural products as antifeedants against stored products insect. PHN\&I 5:17-21.

Ngedwa PM, Thompson SA (2000). Effect of C-to-N ratio on vermicomposting of biosolids. Biores. Technol. 75(1):7-12.

Page AL, Miller DR, Keeney DR (1982). Methods of soil analysis, Part 2, American Society of Agronomy and Soil Science of America, Madison, WI. pp. 674-676.

Palta RK, Bhatnagar RK (2007). Vermiculture: A technology to manage solid wastes. In: Singh SM (ed) Earthworms for Solid Waste Management, International Book Distributing Co., India, pp. 17-50.

Schimel JP, Bennet J (2004). Nitrogen mineralization: Challenges of a changing paradigm. Ecology 85:591-602.

Singh KK, Suman Phogat, Dhillon RS (2009). Neem: A Treatise, I.K. International Publishing House Pvt. Ltd., New Delhi, Bangalore, p. 546.

Suthar S (2009). Vermicomposting of vegetable-market solid waste using Eisenia fetida: Impact of bulking material on earthworm growth and decomposition rate. Ecol. Eng. 35:914-920.

Tabatabai MA (1982). Soil enzymes. In: Page AL, Millar EM, Keeney DR (eds) Methods of Soil Analysis, ASA and SSSA, Madison, W.I., pp. 501-538.

Tan KH (1978). Effects of humic and fulvic acids on release of fixed potassium. Geoderma 21:67-74.

Valdrighi MM, Pera A, Agnolucci M, Frassinetti S, Lunardi D, Vallini G (1996). Effects of compost-derived humic acids on vegetable biomass production and microbial growth within a plant (Cichorium intybus) - soil system: A comparative study. Agric. Ecosyst. Environ. 58:133-144.

Yadav A, Garg VK (2009). Feasibility of nutrient recovery from industrial sludge by vermicomposting technology. J. Hazard. Mater. 168:262268. 